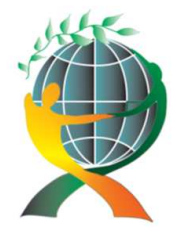

\author{
(online) $=$ ISSN $2285-3642$ \\ ISSN-L = $2285-3642$ \\ Journal of Economic Development, Environment and People \\ Volume7, Issue 2, 2018 \\ URL: http://jedep.spiruharet.ro \\ e-mail: office jedep@spiruharet.ro
}

\title{
Investigating the Role of Tourism in the Conservation and Sustainable Development of the Environment: A Geographic Approach
}

\begin{abstract}
Mahtab Jafari 1 ?
${ }^{1} 1$ M.A. in Political Geography, Department of political geography, Faculty of Geography, University of Tehran, Iran

Abstract. Tourism is always embracing economy, social and environmental impacts. For this reason, the policy of sustainable development of tourism is necessary. The general approach is that governments have paid attention to tourism ecologically in the long run. This is approved and financially self-sufficient, and from the perspective of social and moral for local communities is beneficial and promising. The aim of this study is to evaluate the effects of wetland ecosystem conservation and environmental sustainability of tourism in rural areas. The purpose of applied research and in terms of data collection is descriptive and analytical. The study population consists of 3 villages' khawmirabad rural district, Sarkol Zarivar which in the whole 93 villages of this area, a number of villages was selected. Sample households of the village and randomly classified and 12 villages were selected. Cochran formula used to determine the sample size and questionnaire to 330 randomly selected villages were selected among heads of households. The validity of the test Cronbach's alpha was 0.77 percent. For statistical analysis of data from one sample -t-test, chi-square test and ANOVA test in spss software is used. The results show that tourism in economic and socio-cultural aspects have a positive impact on the conservation and sustainable development of the environment.
\end{abstract}

Keywords: geographic approach, conservation, sustainable development of the environment, tourism.

JEL Codes: L83

How to cite: JAFARI, M. (2018). Investigating the Role of Tourism in the Conservation and Sustainable Development of the Environment:

A Geographic Approach. Journal of Economic Development, Environment and People, 7(2), 6-21. doi: http://dx.doi.org/10.26458/jedep.v7i2.579

\section{Introduction}

In the present era of tourism and tourism economy is becoming one of the fastest growth industries in the world, a tool for the creation of national income and the main pillars of the global economy and also of concepts, forms of development considered (Rattanasuwongchai, 1998: 2). Natural tourism activity is a complex with other sectors of society and the economy, in common, has the effects and consequences of different which should be in the process of planning all its aspects considered the take up of negative factors and threat prevention and the effects of economic, social and environmental aspects related to the increase (Reinholde, 2000). Tourism and environment are mutually dependent. Thus, development and management of tourism so that the environment is a key factor in achieving sustainable development is taken into account

\footnotetext{
+ Corresponding author E-mail address: winter.556611@gmail.com
} 


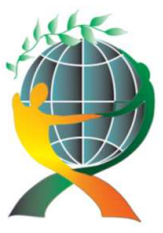

\author{
(online) = ISSN $2285-3642$ \\ ISSN-L = $2285-3642$ \\ Journal of Economic Development, Environment and People \\ Volume 7, Issue 2, 2018 \\ URL: http://jedep.spiruharet.ro \\ e-mail: office jedep@spiruharet.ro
}

(World Tourism Organization, 1379, 73). Tourists need to be part of the natural environment and cultural and human, to the balance between them to maintain (Husain and Altinay, 2005: 274) because the vast majority of recreational activities directly on natural resources in the destination depends (Leich and Dolnicar, 2008: 672). Negative environmental impact of tourism, including air pollution, soil pollution, water pollution, traffic congestion problems, poured spraying waste, damage to historical buildings, destruction of natural herbs, destruction of wildlife, etc. These are (Altinay and Husain, 2005: 277).

Wetlands are beautiful sights if the tourism industry to develop properly planned and managed, can be a creator or drive the development process to achieve sustainable development in their local communities and aquatic ecosystems and wetlands. Wetlands of inertia relative water have been developed, among many ecosystems production in the world, comparable to rain forests and coral reefs, which includes a variety of species of microorganisms, plants, insects, amphibians, reptiles, birds, fish and mammals (Danielle, 2006: 1). The regeneration of this natural ecosystems and restoring natural materials and rustic design of the most important research areas and many of the country's executive (Kirby, 2004). The aim of this study was to evaluate the effects of wetland ecosystem conservation and environmental sustainability of tourism in rural areas surrounding the Zarivar is located in the city of Marivan.

\title{
2. Theoretical Framework
}

\subsection{Tourism}

Today, tourism development and tourism, socio-cultural and environmental and economic impact on tourist areas creates (Zarabi, 2011: 39). Tourism as an important form of human activities has an important impact. The effects in the region where tourism destination with the local environment, economy, culture and society interact is very evident. Also in this context that a large part of the activities of tourism planning is done on the effects of tourism (Mason, 2003: 10). The effects of tourism development, the complex process of change and exchange between tourists and destination host settlements are included (Yoon, 2002: 14).

If tourism can improve the quality of life for residents with the support and acceptance of faces, but if the quality of life of residents through development of tourism more than just the fall, residents little support from the industry are not doing (Muzzo, 2013). Tourism as an important form of human activities has an important impact. The effects in the region where tourism destination with the local environment, economy, culture and society interact is very evident(Lyon, et al,2017: 237). Also in this context that a large part of the activities of tourism planning is done on the effects of tourism (Mason, 2003: 10 ; Mohd Hafiz Hanafiah, et al ,2017 :408). The effects of tourism development, the complex process of change and exchange between tourists and destination hosts include Settlements ways (Yoon, 2002: 14 ; Mihalic, 2016: 464 ). The environmental dimension of tourism, one of the favorite areas of geographers is the reason for this lies in the nature of geography with a robust approach in the field of human relations and the environment (Murphy and Mitchell, 1991: 57). Analysis of tourism on the environment and resources, an area in which natural and 


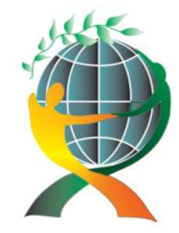

\author{
(online) = ISSN $2285-3642$ \\ ISSN-L = $2285-3642$ \\ Journal of Economic Development, Environment and People \\ Volume7, Issue 2, 2018 \\ URL: http://jedep.spiruharet.ro \\ e-mail: office jedep@spiruharet.ro
}

human geographers study problems related to tourism, are the sharing. However, because of the importance of tourism to the natural environment for activities (Page and Hall, 2002: 1).

\title{
2.2. Wetland ecosystems
}

Lagoon refers to a place where water is the main factor for the environment, plants and animals, so all areas, river, lake, littoral, mangrove forest, Hatcheries, channels, etc. the maximum water depth of more than 3 meters during low tide are not applicable (Convection bureau, 2000). The need for environmental protection and utilization of natural resources, including sustainable development is necessity. Park managers, protected areas and wetlands are faced with the many decisions that need with detailed information of the status quo and causes it to adopt appropriate decision. Cover and dynamic monitoring of land use and landscape in protected areas and wetlands to understand how they Nagy effect on nature, the process of reconstruction and rehabilitation and to protect them in the long term is very important. Assessment of resource and ecological condition of these areas, managers need to make decisions helps (Jones, et al., 2009; Wang, et al: 2009).

Wetlands are among the most important ecosystems on Earth. Safe areas for wildlife in these areas are, however, several are threatened. Wetlands through water are biologically the most diverse ecosystems of the Earth. They have spread across the world and plays an important role in the water cycle, control the regional floods, prevent erosion, water treatment and recirculation of nutrients are caused. They also are transitional zones between land and water environments and as resources become attractive and chemicals, biotechnology and genetics have great value (Mitsch and Gosselink, 1993). Negative human activities greatly affect the wetland ecosystem (Mitsch and Gosselink, 2000; Kent, 2001). Human impacts on wetlands can include physical changes, such as deposition and changes in water flow can also including general biological changes such as loss of biodiversity, the introduction of invasive species and changes in the structure of society (Richardson, 1997; Johnston et al., 2001; Freeland and Richardson, 1997). Wetland habitats are often the first to get the direct impact of physical, biological and chemical activity are common (Holland et al., 1995; Finlayson and Rea, 1999). The major changes by humans to prevent the creation of a healthy habitat for a wide variety of organisms can be. The importance and value of wetlands can be in three parts, including the value of wetlands as wildlife habitat and aquatic plants, the value of wetlands as improving the quality of the environment, socio-economic value of wetlands summarized (Turner, et al., 2000). 


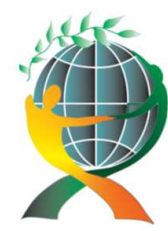

\author{
(online) $=$ ISSN $2285-3642$ \\ ISSN-L = $2285-3642$ \\ Journal of Economic Development, Environment and People \\ Volume 7, Issue 2, 2018
}

URL: http://jedep.spiruharet.ro

e-mail: office jedep@spiruharet.ro

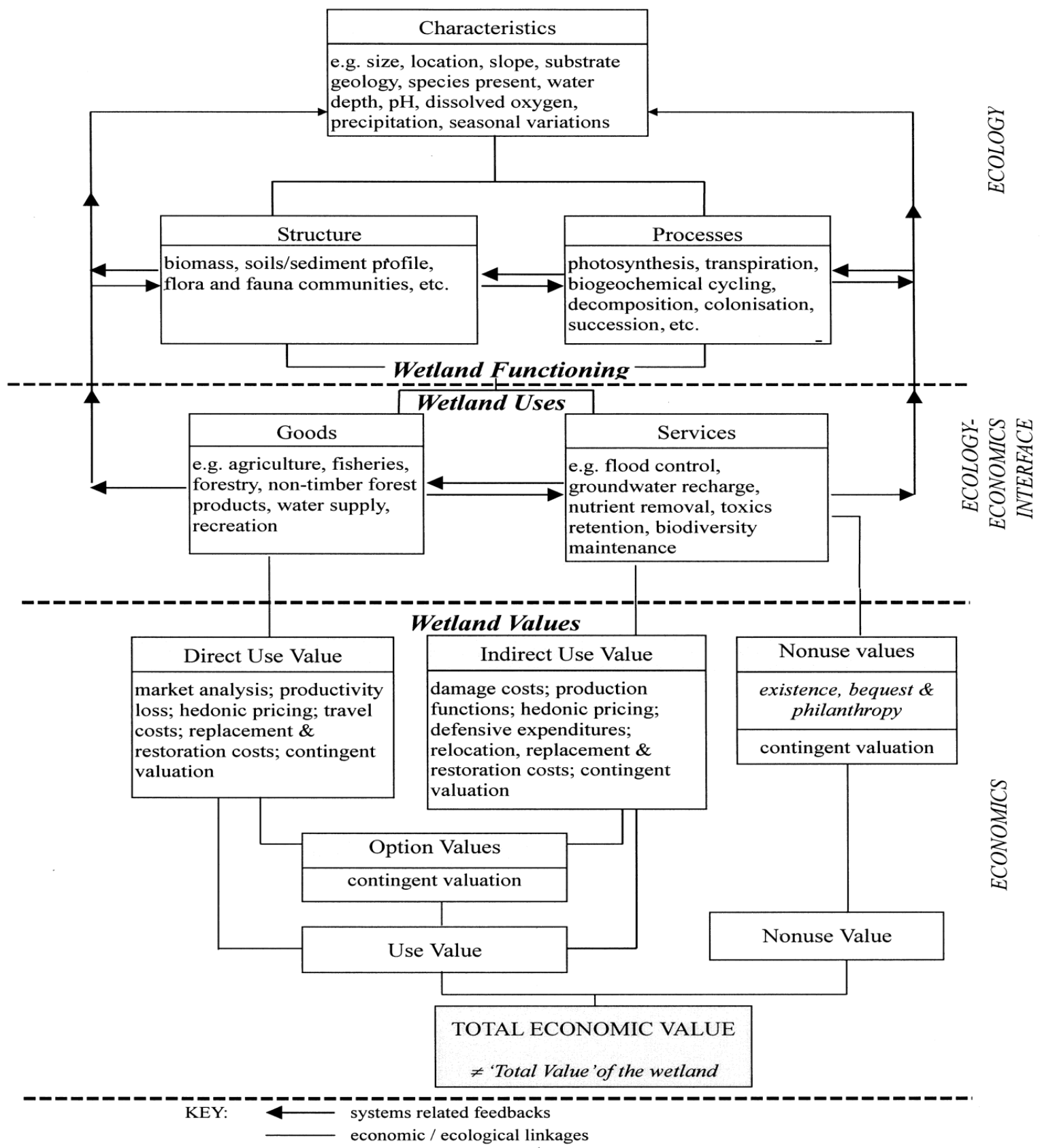

Source: (Turner, 2000).

Fig. 1. Connections among wetland functions, uses and values. 


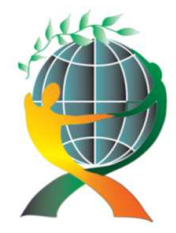

\author{
(online) $=$ ISSN $2285-3642$ \\ ISSN-L = $2285-3642$ \\ Journal of Economic Development, Environment and People \\ Volume7, Issue 2, 2018
}

URL: http://jedep.spiruharet.ro

e-mail: office jedep@spiruharet.ro

Table 1- International studies in the field of research

\begin{tabular}{|c|c|c|}
\hline $\begin{array}{l}\text { The writer } \\
\text { Or writers }\end{array}$ & The subject & Result \\
\hline $\begin{array}{l}\text { Hailun, } \\
\text { Wu \& } \\
\text { Dong }\end{array}$ & $\begin{array}{l}\text { Lake Wetland Management } \\
\text { System Case Study wetland } \\
\text { ecotourism compatibility } \\
\text { with Jin Yan }\end{array}$ & $\begin{array}{l}\text { Wetland ecotourism sustainable development must rely on the } \\
\text { support of local community residents and community involvement } \\
\text { of local communities is an important part of the wetland ecotourism } \\
\text { management. It must be said that in addition to evaluating the } \\
\text { ecological natural phenomenon, the conditions of local communities } \\
\text { in all aspects, including capacity development of eco-tourism, } \\
\text { financial strength, attitude and understanding of local communities, } \\
\text { can contribute a prerequisite for the successful implementation of } \\
\text { ecotourism is. }\end{array}$ \\
\hline $\begin{array}{l}\text { SONGet } \\
\text { al.. }\end{array}$ & $\begin{array}{l}\text { The effects on tourism and } \\
\text { sustainable development of } \\
\text { regional wetland Ning Guy }\end{array}$ & $\begin{array}{l}\text { As a unique wetland ecosystem and enjoyment of rich biodiversity, } \\
\text { functioning and values of environmental, economic and social lot. } \\
\text { Cultural specificity / cultural heritage and biodiversity of wetland } \\
\text { ecosystems has added value. Wetlands having unique natural and } \\
\text { cultural landscape, are appropriate for ecotourism development. }\end{array}$ \\
\hline Dong & $\begin{array}{l}\text { Check the status of the } \\
\text { development of tourism and } \\
\text { protection of wetland } \\
\text { resources in Dongting lake }\end{array}$ & $\begin{array}{l}\text { In summary, managing wetland tourism can realize economic } \\
\text { development, tourism, and yet can support wetland ecological } \\
\text { conservation. }\end{array}$ \\
\hline Lili\& PAN & $\begin{array}{l}\text { A preliminary study on } \\
\text { tourist behavior in a pond }\end{array}$ & $\begin{array}{l}\text { The kinds of wetland ecosystem services, tourism and science } \\
\text { education is very important functions, and wetland ecotourism and } \\
\text { tourism training both new exploitation of wetland resources are } \\
\text { applicable. }\end{array}$ \\
\hline${ }^{1}$ Liu \&Zili & $\begin{array}{l}\text { Case study analyzes the } \\
\text { effects of ecotourism on } \\
\text { Sustainable Development } \\
\text { Lagoon Jin Yan }\end{array}$ & $\begin{array}{l}\text { Lagoon wetland ecotourism is based on natural resources. In fact, } \\
\text { ecotourism wetlands, including wetland ecological culture, which is } \\
\text { ethical and responsible ecotourism characteristics of wetlands, } \\
\text { wetland protection into account and sustainable development of } \\
\text { wetlands protection. }\end{array}$ \\
\hline Wang & $\begin{array}{l}\text { Study the development of } \\
\text { tourism and wetland } \\
\text { ecosystems }\end{array}$ & $\begin{array}{l}\text { Because of its wetlands rich in biodiversity and cultural diversity, } \\
\text { value and function of environmental education tourism is } \\
\text { responsible travel to natural environments that protect the } \\
\text { environment and the economy helps Aboriginal people. Especially in } \\
\text { sensitive and protected areas to reduce the negative environmental } \\
\text { effects caused by the operation will be balanced environment. }\end{array}$ \\
\hline
\end{tabular}

Source: Findings, 2017. 


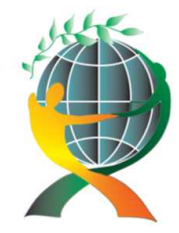

\author{
(online) $=$ ISSN $2285-3642$ \\ ISSN-L = $2285-3642$ \\ Journal of Economic Development, Environment and People \\ Volume 7, Issue 2, 2018
}

URL: http://jedep.spiruharet.ro

e-mail: office jedep@spiruharet.ro

\title{
3. Methodology
}

The purpose of this study and in terms of data collection is descriptive and analytical. Data collection in the theoretical part of the documentary and in the field of survey based on interviews and questionnaires were used. The aim of this study was to evaluate the effects of wetland ecosystem conservation and environmental sustainability of tourism in rural areas. The study population consists of villages 3 Khawmirabad rural district; Sarkol and Zarivarwhich of the 93 villages of this area, a number of villages were selected. Sample households of the village and randomly classified and 12 villages were selected. In field studies, to collect the required data, to prepare a questionnaire and were interviewed between the villages concerned, the most important part of field studies. In field studies, to collect the required data, to prepare a questionnaire and were interviewed between the villages concerned, the most important part of field studies. For this purpose, a questionnaire was designed which included household questionnaire. The questionnaire consisted of closed questions is the question. In designing questions, the Likert scale was used. The validity of the test Cronbach's alpha was 0.77 percent. For statistical analysis of data from one sample $t$ test, chi-square test and ANOVA test in SPSS software is used.

Table 2- Sample villages and distributed questionnaires among them

\begin{tabular}{|c|c|c|c|c|}
\hline Rural district & $\begin{array}{c}\text { The name of } \\
\text { the village }\end{array}$ & $\begin{array}{c}\text { The number } \\
\text { of } \\
\text { households }\end{array}$ & $\begin{array}{c}\text { Total } \\
\text { population }\end{array}$ & $\begin{array}{c}\text { The number of } \\
\text { questionnaires }\end{array}$ \\
\hline \multirow{3}{*}{ Zarivar } & Kanikabod & 41 & 181 & 7 \\
\cline { 2 - 5 } & Siyanav & 196 & 845 & 33 \\
\cline { 2 - 5 } & KaniSanan & 171 & 660 & 28 \\
\cline { 2 - 5 } & Dara tefey & 244 & 924 & 41 \\
\cline { 2 - 5 } & Ney & 656 & 2560 & 55 \\
\hline khawmirabad & Savjey & 280 & 1152 & 44 \\
\cline { 2 - 5 } & Anjiran & 111 & 455 & 22 \\
\cline { 2 - 5 } & Yangijeh & 90 & 362 & 17 \\
\hline \multirow{4}{*}{ Sarkol } & Balek & 139 & 529 & 24 \\
\cline { 2 - 5 } & Darziyan & 112 & 451 & 21 \\
\cline { 2 - 5 } & Sharani & 113 & 472 & 23 \\
\cline { 2 - 5 } & Marg & 89 & 365 & 15 \\
\hline Total & 12 & 41 & 8956 & 330 \\
\hline
\end{tabular}

Source: Findings, 2017.

\subsection{Research Area}

Lagoon flows $3 \mathrm{~km}$ West Marivan in Kurdistan province and the tourist attractions of the province. Sweet pond water is boiling and is funded from a number of source floor. In winter the lake freezes completely. The wetlands in longitude ' $8{ }^{\circ} 46$ latitude ' $32^{\circ} 35$ and the height of 1285 meters above sea level is located. During 


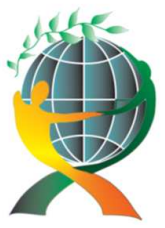

\author{
(online) $=$ ISSN $2285-3642$ \\ ISSN-L = $2285-3642$ \\ Journal of Economic Development, Environment and People \\ Volume7, Issue 2, 2018
}

URL: http://jedep.spiruharet.ro

e-mail: office jedep@spiruharet.ro

Zarivar Lake about $5 \mathrm{~km}$ and a width of about $1.6 \mathrm{~km}$. The extent of wetlands because of changes in the volume of water in different seasons changing and the maximum depth of 5.5 meters.

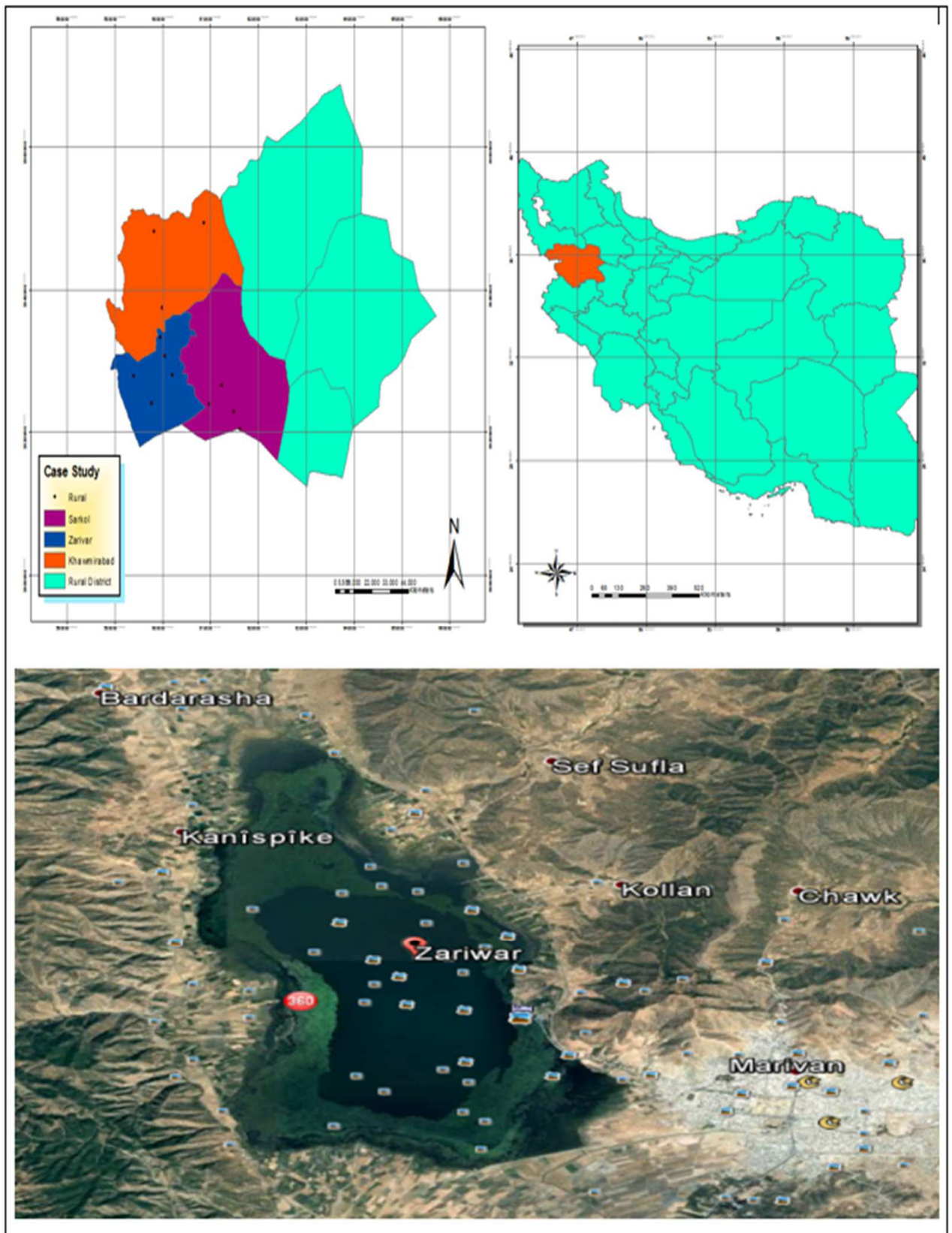

Fig. 2- Location of the study area 


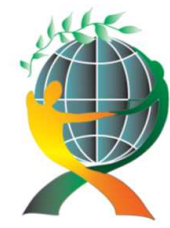

\author{
(online) $=$ ISSN $2285-3642$ \\ ISSN-L = $2285-3642$ \\ Journal of Economic Development, Environment and People \\ Volume 7, Issue 2, 2018
}

URL: http://jedep.spiruharet.ro

e-mail: office jedep@spiruharet.ro

The lagoon's largest and most beautiful fresh water lake west of Iran and one of the most unique freshwater lake in the world and all circumstances considered a wetland of international development. Approximate size pond water is about 30 million cubic meters. Wetland about $22,5 \mathrm{~km}$ and the average rainfall is $786 \mathrm{~mm}$ per year. Relative humidity equal to $4 / 58$ percent and average annual evaporation of 1900 $\mathrm{mm}$ has been reported (Environmental Protection Agency, 1393). Villages of 200 meters to 3 kilometers lagoon flows have been chosen.

The main activity is agriculture and horticulture villages and in some cases to activity in border markets are. Despite the economic situation and tourist lake in the villages around the wetlands have been affected.

\title{
4. Results
}

\subsection{Descriptive Findings}

Descriptive results are presented below:

Table 3- The individual characteristics of respondents in rural areas, border areas

\begin{tabular}{|c|c|c|c|}
\hline \multicolumn{4}{|c|}{ Individual characteristics of respondents } \\
\hline Index & Classification & Frequency & Percent \\
\hline \multirow{5}{*}{ Age } & $15-25$ & 1338 & 100 \\
\hline & $25-35$ & 0 & 0 \\
\hline & $35-45$ & 33 & 15.1 \\
\hline & $45-55$ & 73 & 33.5 \\
\hline & $55>$ & 66 & 30.3 \\
\hline \multirow{5}{*}{$\begin{array}{l}\text { Level of } \\
\text { Education }\end{array}$} & Illiterate & 35 & 16.1 \\
\hline & Primary & 11 & 5.0 \\
\hline & Guidance & 4 & 1.8 \\
\hline & High school & 45 & 20.6 \\
\hline & High school graduate or higher & 63 & 28.9 \\
\hline \multirow{6}{*}{ Main job } & Farmer & 59 & 27.1 \\
\hline & Public services & 47 & 21.6 \\
\hline & Government's employee & 173 & 79.4 \\
\hline & Working & 20 & 9.2 \\
\hline & Dehyaran & 25 & 11.5 \\
\hline & Other & 81 & 37.2 \\
\hline \multirow{5}{*}{$\begin{array}{c}\text { Job } \\
\text { Satisfaction }\end{array}$} & Too much & 44 & 20.2 \\
\hline & A lot & 12 & 5.5 \\
\hline & So much for & 31 & 14.2 \\
\hline & Little & 49 & 22.5 \\
\hline & Very little & 1338 & 100 \\
\hline
\end{tabular}

Source: Findings, 2017. 


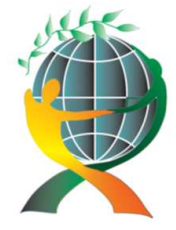

\author{
(online) $=$ ISSN $2285-3642$ \\ ISSN-L = $2285-3642$ \\ Journal of Economic Development, Environment and People \\ Volume7, Issue 2, 2018
}

URL: http://jedep.spiruharet.ro

e-mail: office jedep@spiruharet.ro

Check the individual characteristics of the respondents indicate that all respondents were male, $15.1 \%$ of respondents aged 25-15 years in terms of age, 33.5\% of respondents aged $35-25$ years, $30.3 \%$ of respondents age $45-35$ years, $16.1 \%$ of respondents aged $55-45$ years and $5.0 \%$ in those aged over 55 years have been. In terms of education, 1.8 percent illiterate, $20.6 \%$ of subjects at the elementary level, 28.9 percent of people in the middle, 27.1 percent of high school and 21.6 percent of those in upper secondary level have been nearly 80 percent of people have their home at his residence. Job status among respondents, $37.2 \%$ of agricultural jobs, $20.2 \%$ of public service jobs (shops, taxi driver between rural-urban), $5.5 \%$ of government employees, $14.2 \%$ of self-employed workers and $22.5 \%$ of other work.

Table 4: Dimensions and indicators measured in this study

\begin{tabular}{|c|l|}
\hline Dimension & \multicolumn{1}{c|}{ Criteria } \\
\hline $\begin{array}{c}\text { Ecological__- } \\
\text { environmental }\end{array}$ & $\begin{array}{l}\text { Diversity of flora and fauna, water resources management, management of } \\
\text { wastewater agriculture, organic farming, water pollution lake, nature } \\
\text { conservation and biodiversity, the pollution of the environment, increase } \\
\text { public participation in protecting ecosystems, use of building materials } \\
\text { suitable for harvesting allowed water from the wetland and watershed } \\
\text { wetlands, lack of wastewater management alternatives, the harm to the } \\
\text { animals wetlands) wildlife (land use changes as a result of tourism activities, } \\
\text { shortage of farm and garden organ in the villages of the region, consuming } \\
\text { large amounts of fertilizer and pesticides Chemicals in food production. }\end{array}$ \\
\hline Economic & $\begin{array}{l}\text { Transport facilities, access to weekly markets, poor access to employment } \\
\text { opportunities in the area, lack of eco-cottage industries in rural areas, rural } \\
\text { women's employment, increase the purchasing power of the local } \\
\text { community. }\end{array}$ \\
\hline Sociocultural & $\begin{array}{l}\text { Recognition of the environment, the awareness of people about the } \\
\text { connection between the village and the region, people's belief in wetland } \\
\text { conservation as cultural heritage, lack of opportunities for public participation } \\
\text { in decision-making and programs for the protection of wetlands, } \\
\text { Development Education environmental learning, sense of cooperation in } \\
\text { tourism development and maintenance of wetland ecosystems. }\end{array}$ \\
\hline
\end{tabular}

Source: Findings, 2017. 


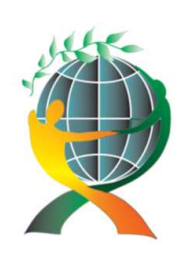

\author{
(online) $=$ ISSN $2285-3642$ \\ ISSN-L = $2285-3642$ \\ Journal of Economic Development, Environment and People \\ Volume 7, Issue 2, 2018
}

URL: http://jedep.spiruharet.ro

e-mail: office jedep@spiruharet.ro

Table 5: Evaluation of the effects of wetland ecosystem conservation and environmental sustainability of tourism in rural areas of the respondents

\begin{tabular}{|c|c|c|c|c|c|c|c|c|c|}
\hline $\begin{array}{l}\text { Dimensi } \\
\text { on }\end{array}$ & Variables & $\begin{array}{l}\text { Too } \\
\text { much }\end{array}$ & Much & Somewhat & Little & $\begin{array}{l}\text { Very } \\
\text { little }\end{array}$ & Average & $\begin{array}{l}\text { Chi- } \\
\text { square }\end{array}$ & Sig \\
\hline \multirow{15}{*}{$\begin{array}{l}\text { Ecologica } \\
\text { I_- } \\
\text { environ } \\
\text { mental }\end{array}$} & Diversity of flora and fauna & 18.70 & 14.00 & 12.50 & 24.00 & 30.80 & 2.32 & 36.555 & .000 \\
\hline & water resource management & 15.30 & 19.30 & 18.10 & 24.30 & 23.10 & 2.21 & 8.735 & 000 \\
\hline & Agricultural waste management & 21.80 & 14.00 & 16.50 & 23.70 & 24.00 & 2.10 & 12.941 & .000 \\
\hline & Organic farming & 31.80 & 15.90 & 23.40 & 5.60 & 23.40 & 3.51 & 61.850 & .000 \\
\hline & $\begin{array}{l}\text { Reducing water pollution in the } \\
\text { lake }\end{array}$ & 15.30 & 6.50 & 26.50 & 20.60 & 31.20 & 2.56 & 59.421 & 000 \\
\hline & $\begin{array}{l}\text { Conservation of Nature and } \\
\text { Biodiversity }\end{array}$ & 20.20 & 11.80 & 16.50 & 25.90 & 25.50 & 2.85 & 23.097 & .000 \\
\hline & $\begin{array}{l}\text { Reduce the pollution of the } \\
\text { environment }\end{array}$ & 12.10 & 4.00 & 18.70 & 27.70 & 37.40 & 2.73 & $\begin{array}{l}109.07 \\
8\end{array}$ & .000 \\
\hline & $\begin{array}{l}\text { Increase women's participation in } \\
\text { the protection of ecosystems }\end{array}$ & 20.60 & 29.90 & 17.80 & 19.60 & 12.10 & 3.27 & 26.523 & 000 \\
\hline & $\begin{array}{l}\text { The use of appropriate building } \\
\text { materials }\end{array}$ & 10.30 & 19.90 & 24.90 & 28.70 & 16.20 & 2.32 & 33.408 & .000 \\
\hline & $\begin{array}{l}\text { Allowed to withdraw water from } \\
\text { the pond }\end{array}$ & 39.60 & 32.40 & 11.80 & 6.20 & 10.00 & 3.82 & $\begin{array}{l}143.37 \\
7 \\
\end{array}$ & .000 \\
\hline & $\begin{array}{l}\text { Alternative Wastewater } \\
\text { Management System }\end{array}$ & 16.20 & 16.80 & 19.60 & 22.40 & 24.90 & 2.60 & 8.798 & 000 \\
\hline & The damage to wetland animals & 4.70 & 9.00 & 28.30 & 35.50 & 22.40 & 2.99 & $\begin{array}{l}107.76 \\
9\end{array}$ & .000 \\
\hline & $\begin{array}{l}\text { Land use change as a result of } \\
\text { tourism activities }\end{array}$ & 17.10 & 22.70 & 12.50 & 23.10 & 23.70 & 3.12 & 16.274 & .000 \\
\hline & $\begin{array}{l}\text { Organic farms and gardens in } \\
\text { rural area }\end{array}$ & 20.20 & 7.80 & 26.20 & 20.20 & 25.50 & 3.70 & 34.997 & 008 \\
\hline & $\begin{array}{l}\text { Fertilizer and chemical pesticides } \\
\text { in agriculture }\end{array}$ & 19.60 & 26.50 & 22.40 & 17.40 & 14.00 & 3.86 & 14.498 & .006 \\
\hline \multirow{7}{*}{$\begin{array}{l}\text { Econom } \\
\text { ic }\end{array}$} & Transport facilities & 24.00 & 34.00 & 20.90 & 16.20 & 5.00 & 3.44 & 72.442 & .001 \\
\hline & Weekly market access & 23.10 & 30.20 & 18.40 & 18.10 & 10.30 & 3.48 & $\begin{array}{l}104.21 \\
8\end{array}$ & 000 \\
\hline & $\begin{array}{l}\text { Access to employment } \\
\text { opportunities in the area }\end{array}$ & 19.30 & 5.60 & 13.40 & 29.00 & 32.70 & 2.50 & $\begin{array}{l}153.93 \\
8\end{array}$ & .000 \\
\hline & Eco cottage industries in villages & 16.20 & 17.40 & 15.30 & 25.90 & 25.20 & 2.50 & $\begin{array}{l}182.59 \\
8\end{array}$ & .000 \\
\hline & Employment for rural women & 17.3 & 23.5 & 20.0 & 29.4 & 9.8 & 3.82 & 27.098 & .000 \\
\hline & $\begin{array}{l}\text { Increase the purchasing power of } \\
\text { the local community }\end{array}$ & 12.2 & 12.2 & & & & & & \\
\hline & $\begin{array}{l}\text { Recognizing the environmental } \\
\text { area }\end{array}$ & 11.8 & 38.4 & 33.3 & 3.25 & $\begin{array}{l}113.84 \\
3\end{array}$ & .000 & & \\
\hline
\end{tabular}




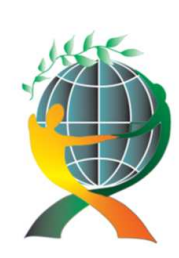

\author{
(online) $=$ ISSN $2285-3642$ \\ ISSN-L = $2285-3642$ \\ Journal of Economic Development, Environment and People \\ Volume7, Issue 2, 2018
}

URL: http://jedep.spiruharet.ro

e-mail: office jedep@spiruharet.ro

\begin{tabular}{|c|c|c|c|c|c|c|c|c|c|}
\hline \multirow{5}{*}{$\begin{array}{l}\text { Sociocul } \\
\text { tural }\end{array}$} & $\begin{array}{l}\text { Awareness of the linkage } \\
\text { between the village and the } \\
\text { region }\end{array}$ & 20.90 & 25.20 & 22.10 & 18.40 & 13.40 & 3.86 & 12.660 & 000 \\
\hline & $\begin{array}{l}\text { People believed to protect the } \\
\text { wetlands as cultural heritage }\end{array}$ & 14.30 & 14.03 & 24.60 & 26.80 & 19.90 & 2.83 & 21.134 & .000 \\
\hline & $\begin{array}{l}\text { Public participation in decision- } \\
\text { making and wetland conservation } \\
\text { programs }\end{array}$ & 29.30 & 37.40 & 13.70 & 11.20 & 8.40 & 3.68 & $\begin{array}{l}102.62 \\
9\end{array}$ & .000 \\
\hline & $\begin{array}{l}\text { Development of environmental } \\
\text { education and learning }\end{array}$ & 13.10 & 19.60 & 17.80 & 28.70 & 20.90 & 2.25 & 20.667 & 000 \\
\hline & $\begin{array}{l}\text { Sense of cooperation in tourism } \\
\text { development and maintenance of } \\
\text { wetland ecosystems }\end{array}$ & 20.0 & 34.5 & 22.7 & 13.3 & 9.4 & 3.58 & 47.765 & .000 \\
\hline
\end{tabular}

Source: Findings, 2017.

In this study in the context of assessing the impact of tourism in maintaining wetland ecosystem and environmental sustainability in rural areas, 27 indicators defined and each of these indicators in SPSS studied and analyzed, which results in Table (6) it has been shown. In this table the consent of respondents to each indicator, average and chi-square is studied. In the field of ecological and environmental dimensions, 15 indicators (diversity of flora and fauna, water resources management, agricultural waste management, organic farming, water pollution lake, nature conservation and biodiversity, the pollution of the environment, increase women's participation in the protection of ecosystems use of construction materials good, picked allow water from the wetland and watershed wetlands, lack of wastewater management alternatives, the harm to the animals wetlands) wildlife (land use changes as a result of tourism activities) used according the optimal numerical test (3), the average on most parameters to measure the low post Favorable than assessed value and alpha level of 0.00 was significant.

One of the main factors in more evaluations performed on the development of tourism in local communities has been emphasized, the economic effects of tourism. Tourism in recent years as a very important economic factor is of great concern. As well as all the places where the tourism industry will need to develop appropriate tourism professionals and executive management. The economic dimension in the study 6 index (transport facilities, access to weekly markets, poor access to employment opportunities in the area, lack of rural industries compatible with the environment in rural areas, employment of rural women, increase the purchasing power of the local community) used according to the mean square of each indicator, tourism had a positive effect on the economic situation of the rural areas of wetland ecosystems. Programs for wetland protection, development of environmental education and learning, sense of cooperation in tourism development and maintenance of wetland ecosystems) have been used. According to the index mentioned that the social dimension of cultural tourism in rural areas of wetland cosystems flows have a positive impact. 


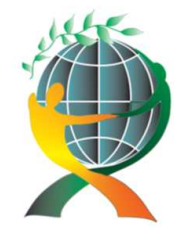

\author{
(online) = ISSN $2285-3642$ \\ ISSN-L = $2285-3642$ \\ Journal of Economic Development, Environment and People \\ Volume 7, Issue 2, 2018
}

URL: http://jedep.spiruharet.ro

e-mail: office jedep@spiruharet.ro

Table 6. The test results T wetland ecosystem conservation and sustainable environment impact of tourism in rural areas

\begin{tabular}{|r|l|l|l|l|l|l|}
\hline Index & $\begin{array}{l}\text { Mean } \\
\text { Difference }\end{array}$ & $\begin{array}{r}\text { Standard } \\
\text { deviation }\end{array}$ & $\begin{array}{l}\text { Index } \\
\text { Ten }\end{array}$ & & Sig & \multicolumn{2}{|l|}{$\begin{array}{l}\text { 95\% Confidence Interval of the } \\
\text { Difference }\end{array}$} \\
\cline { 5 - 7 } & & & & upper & Low \\
\hline $\begin{array}{r}\text { Ecological_- } \\
\text { environmental }\end{array}$ & 2.1169 & 1.209 & 0.007 & 46306 & -.3000 & -.1139 \\
\hline Economic & 3.8131 & 4.374 & .000 & .89774 & 0.0106 & 0.0444 \\
\hline Sociocultural & 3.2764 & $1.479-$ & 0.003 & 31268 & 0.0326 & 0.0046 \\
\hline
\end{tabular}

Source: Findings, 2017.

In one sample T-test number 3 as desirable numerical or theoretical middle test is intended. If the lower and upper limits are positive posts will be larger than the observed value and when both are negative numerical average calculated from the theoretical middle or utility of the test and show less favorable conditions is not. The analysis shows that the level of tourism in economic and socio-cultural aspects has a positive impact on the wetland ecosystem conservation and sustainable environment in rural areas. But after environmental ecological positive impact not only has negative effects on the environment are stable and wetland ecosystems.

Table 7. The analysis of the impact of wetland ecosystem conservation and environmental sustainability of tourism in rural areas

\begin{tabular}{|c|c|c|c|c|c|c|}
\hline \multicolumn{2}{|c|}{ Index } & $\begin{array}{l}\text { Sum of } \\
\text { Squares }\end{array}$ & $d f$ & $\begin{array}{l}\text { Mean } \\
\text { Square }\end{array}$ & $\mathrm{F}$ & Sig. \\
\hline \multirow{3}{*}{$\begin{array}{l}\text { Ecological_- }_{\text {environmental }}\end{array}$} & $\begin{array}{l}\text { Between } \\
\text { Groups }\end{array}$ & 27.814 & 22 & 23.907 & \multirow[t]{3}{*}{24.367} & \multirow[t]{3}{*}{.000} \\
\hline & Within Groups & 260.461 & 357 & .730 & & \\
\hline & Total & 268.275 & 359 & & & \\
\hline \multirow[t]{3}{*}{ Economic } & $\begin{array}{l}\text { Between } \\
\text { Groups }\end{array}$ & 15.517 & 2 & & \multirow[t]{3}{*}{10.318} & \multirow[t]{3}{*}{.000} \\
\hline & Within Groups & 244.865 & 357 & 7.759 & & \\
\hline & Total & 260.383 & 359 & .686 & & \\
\hline \multirow[t]{3}{*}{ Sociocultural } & $\begin{array}{c}\text { Between } \\
\text { Groups }\end{array}$ & .826 & 2 & & \multirow[t]{3}{*}{653.} & \multirow[t]{3}{*}{.000} \\
\hline & Within Groups & 277.507 & 357 & .6 .543 & & \\
\hline & Total & 278.333 & 359 & .777 & & \\
\hline
\end{tabular}

Source: Findings, 2017.

To explain whether the environmental factors of ecological, economic, social and cultural tourism in the wetland ecosystem conservation and environmental sustainability in rural areas there is a significant difference or not, the one-way analysis of variance was used. According to the results table (8) and the significance level $(0.000)$ can be said to amount $F$ for the impact of tourism on wetland ecosystem conservation and environmental sustainability in rural areas has been significant. In other words, this value 


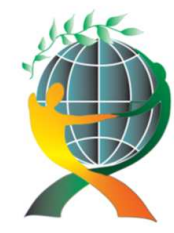

\author{
(online) $=$ ISSN $2285-3642$ \\ ISSN-L = $2285-3642$ \\ Journal of Economic Development, Environment and People \\ Volume7, Issue 2, 2018
}

URL: http://jedep.spiruharet.ro

e-mail: office jedep@spiruharet.ro

indicates that at least there is a significant difference between the two, to check the claim of pairwise comparisons (Tukey) was used in the table (9) refers to it.

Table 8- ANOVA multiple comparisons test

\begin{tabular}{|c|c|c|c|c|c|c|c|}
\hline \multirow[t]{2}{*}{ exam type } & \multirow[t]{2}{*}{ Index } & \multirow[t]{2}{*}{ Rural } & \multirow{2}{*}{$\begin{array}{c}\text { Mean } \\
\text { Difference } \\
(I-J)\end{array}$} & \multirow[t]{2}{*}{$\begin{array}{l}\text { Std. } \\
\text { Error }\end{array}$} & \multirow[t]{2}{*}{.Sig } & \multicolumn{2}{|c|}{$\begin{array}{l}\text { 95\%Confidence } \\
\text { Interval }\end{array}$} \\
\hline & & & & & & $\begin{array}{l}\text { Upper } \\
\text { Bound }\end{array}$ & $\begin{array}{l}\text { Lower } \\
\text { Bound }\end{array}$ \\
\hline \multirow{12}{*}{ Tukey } & \multirow{4}{*}{$\begin{array}{c}\text { Ecologica I__- } \\
\text { environmental }\end{array}$} & \multirow[t]{2}{*}{ Economic } & .32389 & .10066 & .000 & -.0770 & -.5508 \\
\hline & & & .00526 & .12733 & .000 & .2941 & -.3052 \\
\hline & & \multirow[t]{2}{*}{ Sociocultural } & -.32389 & .10066 & .001 & .5508 & .0770 \\
\hline & & & .33833 & .13505 & .001 & .6262 & -.0095 \\
\hline & \multirow{4}{*}{ Economic } & \multirow[t]{2}{*}{ Near } & -.11944 & .09760 & .000 & .3492 & -.1103 \\
\hline & & & .58611 & .12346 & .000 & .8767 & .2955 \\
\hline & & \multirow[t]{2}{*}{ Middle } & .11944 & .09760 & .001 & .1103 & -.3492 \\
\hline & & & .46667 & .13095 & .000 & .7749 & .1585 \\
\hline & \multirow{4}{*}{ Sociocultural } & \multirow[t]{2}{*}{ Near } & -.10236 & .10391 & .000 & .1390 & -.3501 \\
\hline & & & -.06389 & .13143 & .001 & .2454 & -.3732 \\
\hline & & \multirow[t]{2}{*}{ Middle } & .10236 & .10391 & .001 & .3501 & -.1390 \\
\hline & & & .04267 & .13940 & .001 & .3698 & -.2864 \\
\hline
\end{tabular}

Source: Findings, 2017.

Meanwhile, the Kruskal-Wallis test results also show that the alpha level of 0.001 significant wetland ecosystem conservation and environmental impact of tourism in rural areas is sustainable. As the ratings show that an average rural flows to the highest allocated, that may be because it flows near the villages of the district wetland ecosystem in the region. Which impacts (positive and negative) tourism on the ecosystem in the villages.

Table 9-Effect relationship between the villages wetland ecosystem conservation and environmental sustainability of tourism in rural areas Kruskal-Wallis test

\begin{tabular}{|l|c|c|c|}
\hline & Rural district & Count & Average ratings \\
\hline \multirow{4}{*}{$\begin{array}{l}\text { Impact of tourism in } \\
\text { wetland ecosystem } \\
\text { conservation and }\end{array}$} & Khaw and Mirabad & 83 & 163.46 \\
\cline { 2 - 4 } $\begin{array}{l}\text { sustainable } \\
\text { environment }\end{array}$ & Zarivar & 96 & 199.36 \\
\cline { 2 - 4 } & Srkl & 151 & 154.17 \\
\cline { 2 - 4 } & Total & 330 & \\
\cline { 2 - 4 } & Df & 0.001 & \\
\cline { 2 - 4 }
\end{tabular}

Source: Findings, 2017. 


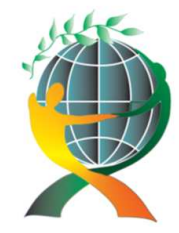

\author{
(online) $=$ ISSN $2285-3642$ \\ ISSN-L = $2285-3642$ \\ Journal of Economic Development, Environment and People \\ Volume 7, Issue 2, 2018 \\ URL: http://jedep.spiruharet.ro \\ e-mail: office jedep@spiruharet.ro
}

\title{
5. Conclusion
}

Development of tourism in an area with tourist arrivals continue to change the landscape of human and natural, socio-cultural changes, economic and environmental ecology. Tourism to provide recreation areas for tourists and create jobs and income for residents of local communities without damaging the environment, local communities and natural ecosystems. One of the tourist areas, are wetland ecosystems that due to the wide range of ecological attractions and unique natural and cultural landscape is highly regarded. The results show that tourism in economic and socio-cultural aspects have a positive impact on the wetland ecosystem conservation and sustainable rural environment. But after environmental ecological positive impact not only has negative effects on the environment are stable and wetland ecosystems. The findings of the Kruskal-Wallis test show that tourism in villages near the wetland ecosystem Zarivar (Yangijeh, Daratefey, Siyanav, Kanikabod, KaniSanan and Ney) are the most affected by the economic dimension of the rural areas studied have had. Also, in the field of the environment (pollution of the lake water, lack of protection of nature and biodiversity, environment pollution, harm to animals, etc.) as well as the most negative impact on the region.

\section{Suggestions}

1. Breach planning and proper management to prevent water pollution and protect the environment and surrounding wetland ecosystem around the lake

2. Encourage people to protect nature and the ecosystem around the lagoon and also avoid harming wildlife wetland ecosystems

3. Provision of infrastructure and services needed by tourists and locals

4. Proper management of water resources and water are allowed harvesting of wetland for tourists and locals

5. Alternative wastewater management systems for rural areas, especially rural areas around the wetland ecosystem.

6. Avoid the use of fertilizers and chemical pesticides in agriculture and horticulture

7. Learning and teaching people to understand the environment and the protection of wetlands as cultural heritage.

\section{References}

[1] Altinay, M. and K. Hussain (2005). "Sustainable Tourism Development: A Case Study of North Cyprus". International Journal of Contemporary Hospitality Management, Volume 17, Issue 3: 272-280.

[2] Andrew Lyon, Philippa Hunter-Jones, Gary Warnaby (2017). Are we any closer to sustainable development? Listening to active stakeholder discourses of tourism development in the Waterberg Biosphere Reserve, South Africa, Tourism Managemen, 234-247. 


\author{
(online) = ISSN $2285-3642$ \\ ISSN-L = $2285-3642$ \\ Journal of Economic Development, Environment and People \\ Volume7, Issue 2, 2018 \\ URL: http://jedep.spiruharet.ro \\ e-mail: office jedep@spiruharet.ro
}

[3] Dolnicar, Sara and Friedrich Leisch (2008). "Selective Marketing for Environmentally Sustainable Tourism". Tourism Management, Volume 29, Issue 4: 672-680.

[4] Dong, M. H (2001). "Study on protection and development of wetland ecotourism resources in Dongting Lake". Resources Science 23(5): 82-86.

[5] Finlayson, C.M., N. Rea (1999). "Reasons for the loss and degradation of Australian wetlands". Wetlands Ecolology and Management, 7 (1-2): 1-11.

[6] Freeland, John A. and Jim L. Richardson (1997). Soils and Sediments as Indicators of Agricultural Impacts on Northern Prairie Wetlands. In: S.A. Peterson, L. Carpenter, G. Guntenspergen and L.M. Cowardin (eds.), Pilot Test of Wetland Condition Indicators in the Prairie Pothole Region of the United States. Washington DC: US Environmental Protection Agency, pp.119-144.

[7] Hailun, Wu \& Dong, Xu, (2011). Construction of Wetland Ecotourism Management System, Case Study for Wetland in Jinyin Lake, International Conference of E Business and E Government (ICEE), China, 6-8 May.

[8] Hall, Michael and Stephen Page (2002). The Geography of Tourism and Recreation: Environment, Place and Space. London and New York: Routledge.

[9] Holland, C.C.; Honea, J.; Gwin, S.E.; Kentula, M.E. (1995). "Wetland degradation and losing the rapidly urbanizing area of Portland, Oregon". Wetlands 15 (4): 336-345.

[10] Jones, D.A. et al. (2009). “Monitoring land use and cover around parks: A conceptual approach". Remote Sensing of Environment, 113: 1346-1356.

[11] Johnston, C.A., Bridgham, S.D., Schubauer-Berigan, J.P. (2001). "Nutrient dynamics in relation to geomorphology of river wetlands". Soil Science Society of America Journal, 65: 557-577.

[12] Kent, Donald M. (ed.). (2000). Applied Wetlands Science and Technology. $2^{\text {nd }}$ edition. New York: Lewis Publishers.

[13] Liu, Zili, Xinfa Dong, Zhaotie Liu, Qihai Liu (2013). “A Simple Analysis on Wetland Ecotourism Sustainable Development: Case Study for Jinyin Lake". Advanced Materials Research, Vol. 807 - 809: 91091-4.

[14] Mason, Peter. (2003). Tourism Impacts, Planning and Management. Jordan Hill: Routledge.

[15] Mitchell, Lisle S., Peter E. Murphy (1991). "Geography and tourism”. Annals of Tourism Research, Volume 18, Issue 1: 57-70.

[16] Mohd Hafiz Hanafiah , Inoormaziah Azman, Mohd Raziff Jamaluddin, Norliza Aminuddin (2016), Responsible Tourism Practices and Quality of Life: Perspective of Langkawi Island communities Procedia - Social and Behavioral Sciences,406-413.

[17] Muzzo, U. (2013). Quality of life of residents and sustainability in the destination community: emerging research areas. Conference of Tourism \& Hospitality: The Highway to Sustainable Regional Development, June 28-30, 2013, Yerevan, Armenia .

[18] PAN, Lili, Lijuan CUI, Ming WU (2010). "Tourist Behaviors in Wetland Park: A Preliminary Study in Xixi National Wetland Park, Hangzhou, China". Chinese Geographical Science, Vol. 20, No. 1: 66 -73.

[19] Piagentini, Nejma Danielle (2006). The Science and Policy that Compels the Wetland Mitigation of Phosphate-Mined Lands. Master of Science Thesis, University of South Florida.

[20] P.V. Mathew, S. Sreejesh (2017), Impact of responsible tourism on destination sustainability and quality of life of community in tourism destinations, Journal of Hospitality and Tourism Management ,83-89. 


\author{
(online) = ISSN $2285-3642$ \\ ISSN-L = $2285-3642$ \\ Journal of Economic Development, Environment and People \\ Volume 7, Issue 2, 2018 \\ URL: http://jedep.spiruharet.ro \\ e-mail: office jedep@spiruharet.ro
}

[21] Rattanasuwongchai, N. (1998): Rural Tourism: The Impact on Rural Communities, 2. Thailand Food and Fertilizer Technology Center.

[22] Reinhold, T.K. and A. Diara (2000). "The role of tourism in development planning". Department of Business Management.

[23] SONG, Chun-Ling and Xiao-Hu QUAN (2007). "Sustainable Development of Wetland Ecotourism in Ningxia Hui Region". Wetland Science, Vol. 2.

[24] Tanja Mihalic (2016). Sustainable-responsible tourism discourse e Towards 'responsustable' tourism, Journal of Cleaner Production ,461-470.

[25] Turner, K.T., J. Bergh, T. Barendregt, J. Straaten and E. Maltby (2000). “Ecological-economic analysis of wetlands: scientific integration for management and policy". Ecological Economics, Volume 35, Issue 1: 7-23.

[26] Wang, Y.Q. et al. (2009). "Remote sensing of land-cover change and landscape context of the national parks: A case study of the Northeast Temperate Network". Remote Sensing of Environment, 113: 1453-1461.

[27] Wazin, N. (2014). "Developing pattern of strategic planning for the development of wetland ecotourism towards wetland ecosystem health and sustainability of rural communities about the range of wetlands Miankale and lapo wetlands". Journal of Research Spatial Planning (Geography), Issue II: 174-153.

[28] World Tourism Organization 1379, "National and regional tourism planning". Translated by M.A. Zadeh. Tehran: Cultural Research Bureau.

[29] Yoon, Y. (2002). Development of a Structural Model for Tourism Destination Competitiveness from Stakeholders, Perspectives. PhD Thesis. Virgin Polytechnic Institute. 